\title{
Synthesis, Characterization, Crystal Structure, and Biological Studies of a Cadmium(II) Complex with a Tridentate Ligand $4^{\prime}$-Chloro-2, $2^{\prime}: 6^{\prime}, 2^{\prime \prime}$-Terpyridine
}

\author{
L. A. Saghatforoush, ${ }^{1}$ L. Valencia, ${ }^{2}$ F. Chalabian, ${ }^{3}$ and Sh. Ghammamy ${ }^{4}$ \\ ${ }^{1}$ Chemistry Department, Payame Noor University, Tehran 19395-4697, Iran \\ ${ }^{2}$ Departamento de Quimica Inorganica, Facultad de Quimica, Universidade de Vigo, 36310 Vigo, Spain \\ ${ }^{3}$ Department of Biology, Islamic Azad University, Tehran North Campus, Tehran, Iran \\ ${ }^{4}$ Department of Chemistry, Imam Khomeini International University, Qazvin 34149-16818, Iran
}

Correspondence should be addressed to L. A. Saghatforoush, saghatforoush@gmail.com

Received 25 January 2011; Revised 23 March 2011; Accepted 24 March 2011

Academic Editor: Giovanni Natile

Copyright $\odot 2011$ L. A. Saghatforoush et al. This is an open access article distributed under the Creative Commons Attribution License, which permits unrestricted use, distribution, and reproduction in any medium, provided the original work is properly cited.

A new Cd(II) complex with the ligand $4^{\prime}$-chloro-2,2' $6^{\prime}, 2^{\prime \prime}$-terpyridine (Cltpy), [Cd(Cltpy)(I $\left.)_{2}\right]$, has been synthesized and characterized by $\mathrm{CHN}$ elemental analysis, ${ }^{1} \mathrm{H}-\mathrm{NMR},{ }^{13} \mathrm{C}-\mathrm{NMR}$, and IR spectroscopy and structurally analyzed by X-ray singlecrystal diffraction. The single-crystal X-ray analyses show that the coordination number in complex is five with three terpyridine (Cltpy) N-donor atoms and two iodine atoms. The antibacterial activities of Cltpy and its Cd(II) complex are tested against different bacteria.

\section{Introduction}

Terpyridine molecules with three nitrogen atoms acting as tridentate ligands to coordinate with various transition metal ions have been extensively studied $[1,2]$. Coordination chemistry of the multitopic ligand of $2,2^{\prime}: 6^{\prime}, 2^{\prime \prime}$ terpyridine (tpy) particularly those substituted at the 4-position has been recently attracting growing attention in the design of the supramolecular building blocks based on the metaldirected self-assembly [3-26]. The $4^{\prime}$-chloro-2,2':6',2' -terpyridine (Cltpy) ligand (Figure 1) contains one widely used tpy coordinative site and the other $\mathrm{Cl}$ site at the $4^{\prime}$-position. These two sites are able to bind with different metal ions, thus leading to the coordination polymers with various frameworks [21]. Tpy can bind to both low- and high-oxidation state metal ions, almost always in tridentate fashion [2732]. The synthesis of tpy derivatives has been extensively studied by Constable's group, and varieties of substituted tpy compounds have been reported [19, 20]. For example, they offered interesting prospects for metal-activated drug delivery system, where the activity could be switched by metal-ion coordination through the study of the interactions between bioreceptors and ligand with sugar substituents [19, 20]. In clinical applications and biochemistry, functionalized terpyridines have found a wide range of potential uses, ranging from colorimetric metal determination to DNA binding agents [33]. Metal terpyridine complexes due to the binding to nucleic acids have the ability or potential to serve as anticancer, antibacterial, and antiparasitic drugs [34-39]. The exact mechanisms are not known in some cases and may involve protein binding or membrane binding. The interaction Cd(II) ion with biomolecules is one of the most studying fields in coordination chemistry, and cadmium is a very toxic metal and widely used in many industrial processes $[40,41]$. In this research we used new tridentate ligand $4^{\prime}$ chloro-2,2': $6^{\prime}, 2^{\prime \prime}$-terpyridine (Cltpy) that has been used for synthesis of a new cadmium(II) complex. The structural and biological properties of this new complex have been studied. 
<smiles>Clc1cc(-c2ccccn2)nc(-c2ccccn2)c1</smiles>

FIgURE 1: Structure of Cltpy ligand.

\section{Experimental}

2.1. Materials and Measurements. All chemicals were reagent grade and used without further purification. Elemental analyses $(\mathrm{CHN})$ were performed using a Carlo ERBA model EA 1108 analyzer. FT-IR spectra were collected on a Shimadzu prestige 21 spectrophotometer in the range of 4000 $400 \mathrm{~cm}^{-1}$ using $\mathrm{KBr}$ pellets. ${ }^{1} \mathrm{H}$ and ${ }^{13} \mathrm{C}$ NMR spectra were recorded with a Bruker spectrometer at $250 \mathrm{MHz}$ in $\mathrm{D}_{6}$ DMSO.

2.2. Preparation of $\left[C d(C l t p y)(I)_{2}\right] .4^{\prime}$-chloro- $2,2^{\prime}: 6^{\prime}, 2^{\prime \prime}$-terpyridine $(0.268 \mathrm{~g}, 1 \mathrm{mmol})$ was placed in one arm of a branched tube, cadmium(II) acetat $(0.264 \mathrm{~g}, 1 \mathrm{mmol})$ and potassium iodide $(0.332 \mathrm{~g}, 2 \mathrm{mmol})$ in the other. Methanol was carefully added to fill both arms, the tube was then sealed, and the ligand-containing arm was immersed in a bath at $60^{\circ} \mathrm{C}$, while the other remained at ambient temperature. After two days, the light brown crystals that had deposited in the cooler arm were filtered off, then washed with diethylether, and air dried. Yield: 71\%. Analysis: found: C: $28.38, \mathrm{H}: 1.51, \mathrm{~N}: 6.59 \%$. Calculated for $\mathrm{C}_{15} \mathrm{H}_{10} \mathrm{CdClI}_{2} \mathrm{~N}_{3}$ : C: $28.42, \mathrm{H}: 1.59, \mathrm{~N}, 6.63 \%$. IR $\left(\mathrm{cm}^{-1}\right)$ selected bonds: $679(\mathrm{w}), 798(\mathrm{~s}), 822(\mathrm{~m}), 1005(\mathrm{~m}), 1142(\mathrm{w})$, 1405(s), 1475(m), 1545(s), 1582(s), 3042(w), 3065(w). ${ }^{1} \mathbf{H}$ NMR (DMSO, $\delta): 7.49(\mathrm{t}, 2 \mathrm{H}), 8.011(\mathrm{t}, 2 \mathrm{H}), 8.404(\mathrm{~s}, 2 \mathrm{H})$, $8.684(\mathrm{~m}, 4 \mathrm{H}) \mathrm{ppm} .{ }^{13} \mathrm{C}$ NMR (DMSO, $\left.\delta\right): 120.46,121.06$, $124.34,135.31,140.65,146.52,152.12,155.36$ ppm.

2.3. Antibacterial Activity Test. In vitro activity test was carried out using the growth inhibitory zone (well method) [42-45]. The potency of components was determined against the three Gram-positive bacteria, Streptococcus pyogenes (RITCC 1940), Staphylococcus aureus (RITCC 1885), and Bacillus anthracis (RITCC 1036), and also against the three Gram-negative bacteria, Klebsiella pneumonia (RITCC 1249), Escherichia coli (RITCC 1330), and Pseudomonas aeruginosa (RITCC 1547). Microorganisms (obtained from enrichment culture of the microorganisms in $1 \mathrm{~mL}$ MullerHinton broth incubated at $37^{\circ} \mathrm{C}$ for $12 \mathrm{~h}$ ) were cultured on Muller-Hinton agar medium. The inhibitory activity was compared with that of standard antibiotics, such as gentamicin $(10 \mu \mathrm{g})$. After drilling wells on the medium using a $6 \mathrm{~mm}$
TABLe 1: Crystallographic data of $\left[\mathrm{Cd}(\mathrm{Cltpy}) \mathrm{I}_{2}\right.$ complex.

\begin{tabular}{|c|c|}
\hline Identification code & $\mathrm{Cd}$ (terpy-Cl) $\mathrm{I}_{2}(7)$ \\
\hline Empirical formula & C15 H10 Cd Cl I2 N3 \\
\hline Formula weight & 633.91 \\
\hline Colour & light brown \\
\hline Temperature & $293(2) \mathrm{K}$ \\
\hline Wavelength & $0.71073 \mathrm{~A}$ \\
\hline Crystal system & Monoclinic \\
\hline Space group & $\mathrm{P} 2(1) / \mathrm{c}$ \\
\hline \multirow[t]{6}{*}{ Unit cell dimensions } & $a=11.4865(10) \AA$ \\
\hline & $b=8.9326(7) \AA$ \\
\hline & $c=17.7570(14) \AA$ \\
\hline & $\alpha=90^{\circ}$ \\
\hline & $\beta=94.242(2)^{\circ}$ \\
\hline & $\gamma=90^{\circ}$ \\
\hline Volume & $1817.0(3) \AA^{3}$ \\
\hline $\mathrm{Z}$ & 4 \\
\hline Density (calculated) & $2.317 \mathrm{~g} \mathrm{~cm}^{-3}$ \\
\hline Absorption coefficient & $4.745 \mathrm{~mm}^{-1}$ \\
\hline$F(000)$ & 1168 \\
\hline Crystal size & $0.27 \times 0.14 \times 0.13 \mathrm{~mm}^{3}$ \\
\hline Theta range for data collection & 1.78 to $25.02^{\circ}$ \\
\hline \multirow[t]{3}{*}{ Index ranges } & $-11 \leq h \leq 13$ \\
\hline & $-10 \leq k \leq 10$ \\
\hline & $-21 \leq l \leq 19$ \\
\hline Reflections collected & 9236 \\
\hline Independent reflections & 3184 \\
\hline Absorption correction & Empirical \\
\hline Max. and min. transmission & 0.5774 and 0.3606 \\
\hline \multirow[t]{2}{*}{ Refinement method } & Full-matrix \\
\hline & least-squares on $F^{2}$ \\
\hline Data/restraints/parameters & $3184 / 0 / 199$ \\
\hline Goodness-of-fit on $F^{2}$ & 1.063 \\
\hline \multirow[t]{2}{*}{ Final $R$ indices $[I>2 \sigma(I)]$} & $R_{1}=0.0309$ \\
\hline & $w R_{2}=0.0747$ \\
\hline \multirow[t]{2}{*}{$R$ indices (all data) } & $R_{1}=0.0504$ \\
\hline & $w R_{2}=0.0862$ \\
\hline Largest diff. peak, hole & 0.802 and $-0.708 \mathrm{e} \cdot \AA^{-3}$ \\
\hline
\end{tabular}

cork borer, $100 \mu \mathrm{L}$ of solution from different compounds were poured into each well. The plates were incubated at $37^{\circ} \mathrm{C}$ overnight. The diameter of the inhibition zone was measured as precisely as possible. Each test was carried out in triplicate, and the average was calculated for inhibition zone diameters. A blank containing only DMSO showed no inhibition in a preliminary test. The macrodilution broth susceptibility assay was used for the evaluation of minimal inhibitory concentration (MIC). The use of 12 test tubes is required by the macrodilution method. By including $1 \mathrm{~mL}$ Muller-Hinton broth in each test and then adding $1 \mathrm{~mL}$ extract with concentration $100 \mathrm{mg} / \mathrm{mL}$ in the first tube, we made a serial dilution of this extract from the first tube to the last tube. Bacterial suspensions were prepared to match 


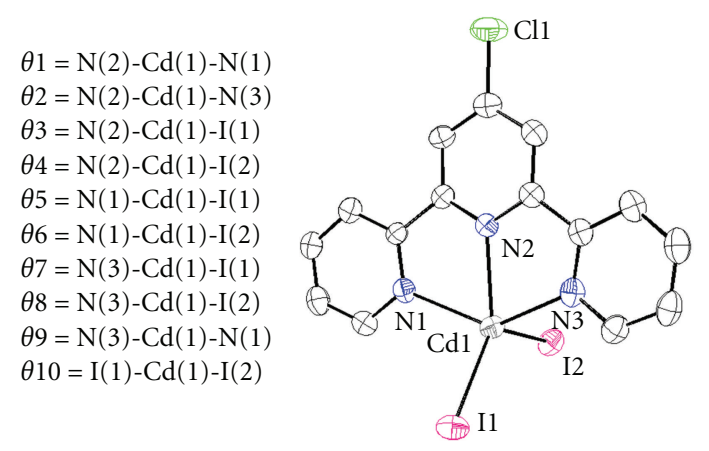

Figure 2: Molecular structure of $\left[\mathrm{Cd}(\mathrm{Cltpy}) \mathrm{I}_{2}\right]$ including the atom numbering scheme. All hydrogen atoms have been omitted for clarity.

the turbidity of 0.5 McFarland turbidity standards. Matching this turbidity provided bacterial inoculums concentration of $1.5 \times 10^{8} \mathrm{cfu} / \mathrm{mL}$. Then $1 \mathrm{~mL}$ of bacterial suspension was added to each test tube. After incubation at $37^{\circ} \mathrm{C}$ for $24 \mathrm{~h}$, the last tube was determined as the minimal inhibitory concentration (MIC) without turbidity.

\subsection{X-Ray Crystallography}

2.4.1. Structure Determination. Data collection for X-ray crystal structure determination was performed on a STOE IPDS I/II diffractometer using graphite-monochromated Mo- $\mathrm{K}_{\alpha}$ radiation $(\lambda=0.71073 \AA)$. The data were corrected for Lorentz and polarization effects. A numerical absorption correction based on crystal-shape optimization was applied for all data. The programs used in this work are Stoe's XArea, including X-RED and X-Shape for data reduction and absorption correction, and the WinGX suite of programs, including SIR-92 and SHELXL-97 for structure solution and refinement [46]. The hydrogen atoms were placed in idealized positions and constrained to ride on their parent atom. The last cycles of refinement included atomic positions for all atoms, anisotropic thermal parameters for all nonhydrogen atoms, and isotropic thermal parameters for all hydrogen atoms. Materials for publication were prepared by using Mercury and Ortep-3 $[47,48]$. The summary of the crystal data, experimental details, and refinement results of complex is listed in Table 1.

\section{Results and Discussion}

3.1. Spectroscopic Studies. The reaction of $\mathrm{CdX}_{2}$ (X: nitrate and acetate) with $4^{\prime}$-chloro-2,2':6', $2^{\prime \prime}$-terpyridine (Cltpy) and potassium iodide yielded crystalline material formulated as $\left[\mathrm{Cd}(\mathrm{Cltpy})(\mathrm{I})_{2}\right]$. The IR spectra display characteristic absorption bands for the tpyCl ligands. The relatively weak absorption bands at around $3042-3065 \mathrm{~cm}^{-1}$ are due to the C$\mathrm{H}$ modes involving the aromatic ring hydrogen atoms. The absorption bands with variable intensity in the frequency
TABle 2: Selected bond lengths/Å and angles ${ }^{\circ}$.

\begin{tabular}{rccc}
\hline \multicolumn{4}{c}{$\left[\mathrm{Cd}(\right.$ Cltpy $\left.) \mathrm{I}_{2}\right]$} \\
\hline Cd1-N1 & $2.373(5)$ & $\theta 3$ & $135.19(11)$ \\
Cd1-N2 & $2.331(5)$ & $\theta 4$ & $106.17(11)$ \\
Cd1-N3 & $2.381(5)$ & $\theta 5$ & $101.35(12)$ \\
Cd1-I1 & $2.7311(8)$ & $\theta 6$ & $101.13(13)$ \\
Cd1-I2 & $2.7523(7)$ & $\theta 7$ & $101.33(13)$ \\
& & $\theta 8$ & $99.34(13)$ \\
$\theta 1$ & $69.24(17)$ & $\theta 9$ & $130.94(18)$ \\
$\theta 2$ & $68.81(18)$ & $\theta 10$ & $118.63(2)$ \\
\hline
\end{tabular}

range $1400-1620 \mathrm{~cm}^{-1}$ correspond to aromatic ring vibrations of the tpyCl ligand [29-40,49].

The ${ }^{1} \mathrm{H}$-NMR spectra of DMSO solutions of complex at room temperature show two triplets, a singlet, and a multiplet for the aromatic protons of Cltpy ligand. The ${ }^{13} \mathrm{C}-$ NMR spectra of DMSO solutions of these compounds show eight distinct bands assigned to the aromatic carbon atoms of the pyridine rings of the Cltpy ligand.

3.2. Structural Analysis. The solid-state structure of compound was determined by single-crystal X-ray diffraction. Crystal and structure refinement data of the compound are given in Table 1. X-ray crystal analysis reveals that the compound crystallizes in monoclinic with space group $\mathrm{P} 2(1) / c$. The crystal structure of compound consists of monomeric units. Each cadmium atom chelated by three Cltpy nitrogen atoms and two iodine atoms (Figure 2). The resulting coordination number of five is augmented with $\mathrm{CdN}_{3} \mathrm{I}_{2}$ molecule core. Selected bond lengths and angels of complex are given in Table 2.

The complex structure was described in detail. Five coordinate complexes with chelating ligands can exhibit either square pyramidal or trigonal bipyramidal geometries, and the particular case is influenced by both steric and electronic factors. The variation of five coordinate species between square pyramidal and trigonal bipyramidal is quantified using $\tau$ values calculated by (1), where $\beta$ is the largest $\mathrm{X}-$ $\mathrm{Cu}-\mathrm{X}$ bond angle and $\alpha$ is the second largest $\mathrm{X}-\mathrm{Cu}-\mathrm{X}$ angle. For the regular square pyramidal structures the trigonality parameter $\tau$ will be zero, and it increases to 1.0 as the trigonal bipyramidal distortion increases [50-52]:

$$
\tau=\frac{(\beta-\alpha)}{60} .
$$

The new $\left[\mathrm{Cd}(\mathrm{Cltpy})(\mathrm{I})_{2}\right]$ complex reported herein takes on a slightly distorted square pyramidal structure as evidenced by the $\tau$ value of 0.029 . Definition of the bond angles $(\theta)$ in $\left[\mathrm{Cd}(\mathrm{Cltpy})(\mathrm{I})_{2}\right]$ complex is illustrated in Figure 1. The Cd1$\mathrm{N} 1, \mathrm{Cd} 1-\mathrm{N} 2$, and $\mathrm{Cd} 1-\mathrm{N} 3$ bond lengths are within the normal range of $\mathrm{Cd}-\mathrm{N}$ bonds. The average bond length of $\mathrm{Cd}-\mathrm{I}$ is 2.7417 (7) $\AA$ that is slightly shorter than the reported bond length [53]. The I2 occupies the apical position in complex at relatively longer distance. The rigid character of the tpy bite leads $\mathrm{Cd}-\mathrm{N}$ bond lengths in the complex to follow the general trend of Cdtpy complexes, that is, to have their $\mathrm{Cd}-\mathrm{N}$ 


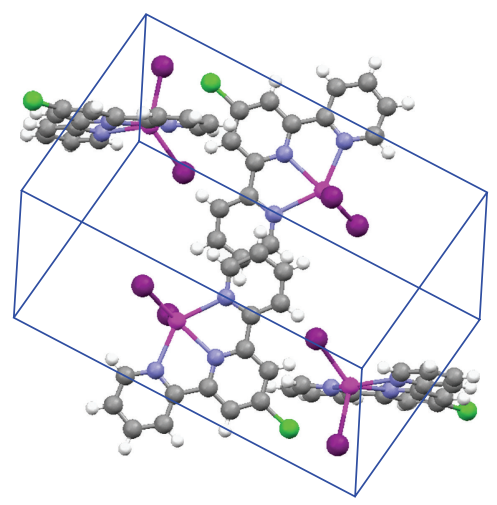

(a)

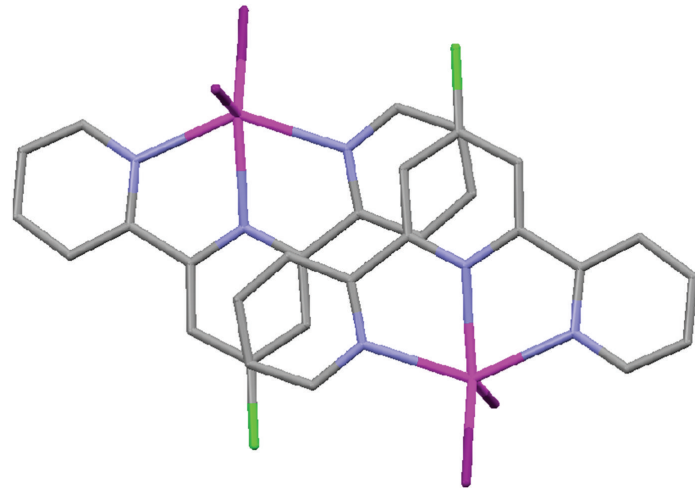

(b)

Figure 3: (a) The unit cell of $\left[\mathrm{Cd}(\mathrm{Cltpy}) \mathrm{I}_{2}\right]$. (b) Close-up view of the aromatic $\pi-\pi$ contacts showing ligand overlap (slipped face-to-face interaction).

TABLE 3: Intermolecular interactions in crystals of $\left[\mathrm{Cd}(\mathrm{Cltpy}) \mathrm{I}_{2}\right]$ complex.

\begin{tabular}{lcc}
\hline $\mathrm{A} \cdots \mathrm{H}-\mathrm{B}$ & $\mathrm{H} \cdots \mathrm{A} / \AA$ & $\mathrm{B} \cdots \mathrm{A} / \AA$ \\
$\mathrm{I} 2 \cdots \mathrm{H} 14-\mathrm{C} 14(-x, y,-z+1 / 2)$ & 2.937 & $3.620(2)$ \\
$\mathrm{I} 2 \cdots \mathrm{H} 12-\mathrm{C} 12(-x, y,-z+1 / 2)$ & 3.130 & $3.435(2)$ \\
$\mathrm{I} 2 \cdots \mathrm{H} 13-\mathrm{C} 13(-x, y,-z+1 / 2)$ & 3.163 & $3.308(2)$ \\
$\mathrm{C} 2(\mathrm{~N} 1 \mathrm{C} 1-\mathrm{C} 5) \cdots \mathrm{C} 8(\mathrm{~N} 2 \mathrm{C} 6-\mathrm{C} 10)$ & & $3.472(3)$ \\
Centroid $\cdots$ centroid $(\mathrm{N} 1 \mathrm{C} 1-\mathrm{C} 5) \cdots(\mathrm{N} 2 \mathrm{C} 6-\mathrm{C} 10)$ & & $3.818(2)$ \\
Centroid $\cdots$ centroid $(\mathrm{N} 3 \mathrm{C} 11-\mathrm{C} 15) \cdots(\mathrm{N} 3 \mathrm{C} 11-\mathrm{C} 15)$ & & $4.275(2)$ \\
\hline
\end{tabular}

TABLE 4: Antibacterial activities (zone of growth inhibition and minimal inhibitory concentrations) of Cltpy ligand and Cd (II) complex and gentamicin (as a standard compound).

\begin{tabular}{|c|c|c|c|c|c|c|c|}
\hline \multirow{2}{*}{ Method } & \multirow{2}{*}{ Main compounds } & \multicolumn{6}{|c|}{ Microorganisms } \\
\hline & & $\begin{array}{c}\text { Klebsiella } \\
\text { pneumonia (-) }\end{array}$ & $\begin{array}{c}\text { Escherichia } \\
\text { coli }(-)\end{array}$ & $\begin{array}{c}\text { Pseudomonas } \\
\text { aeruginosa }(-)\end{array}$ & $\begin{array}{l}\text { Streptococcus } \\
\text { pyogenes }(+)\end{array}$ & $\begin{array}{c}\text { B. anthracis } \\
(+)\end{array}$ & $\begin{array}{c}\text { Staphyeococcus } \\
\text { aureus }(+)\end{array}$ \\
\hline \multirow{2}{*}{$\begin{array}{l}\text { Growth Inhibitory } \\
\text { zone }[\mathrm{mm}]\end{array}$} & Cltpy & 10 & 15 & 20 & 30 & 25 & 15 \\
\hline & Complex & 10 & 20 & 20 & 10 & 12 & 10 \\
\hline Standard & Gentamicin & 20 & 25 & 15 & 13 & 32 & 20 \\
\hline \multirow{2}{*}{$\begin{array}{l}\text { Minimum inhibitory } \\
\text { concentration } \\
(\mathrm{mg} / \mathrm{mL})(\mathrm{MIC})\end{array}$} & $\mathrm{L}$ & 100 & 100 & 50 & 6.25 & 12.5 & 100 \\
\hline & Complex & 100 & 50 & 50 & 100 & 100 & 100 \\
\hline
\end{tabular}

central bond slightly shorter than the Cd-N lateral $[54,55]$. The tpy ligand is not planar; due to coordination strain the molecule is bent into a concave shape, the central pyridyl group subtending dihedral angles of 5.85(1) and $9.19(1)^{\circ}$ to the lateral ones.

This complex has some intermolecular interactions. Intermolecular interactions in crystal of $\left[\mathrm{Cd}(\mathrm{Cltpy}) \mathrm{I}_{2}\right]$ complex are shown in Table 3 . There are aromatic $\pi-\pi$ stacking interactions between the parallel aromatic rings of the $4^{\prime}$-chloro-2,2': $6^{\prime}, 2^{\prime \prime}$-terpyridine (Cltpy) ligands as seen in Figure 3(b).

The unit cell of complex is shown in Figure 2. Molecules occupied half of tetrahedral holes and used zinc blend system that is not a closed packed system.
3.3. Antibacterial Activity. The antibacterial activities of Cltpy and its Cd(II) complex are shown in Table 4. The free ligand has considerable activity against Staphylococcus pyogenes, Bacillus anthracis, and Pseudomonas aeruginosa (inhibitory zones $\geq 20 \mathrm{~mm}$ ) but has moderate activity against Escherichia coli and Streptococcus aureus (inhibitory zones $\leq 15 \mathrm{~mm}$ ) [42, 43]. In comparison with free Cltpy ligand, the complex has more activity against Escherichia coli (more inhibitory zones), but it is less active against Staphylococcus pyogenes, Bacillus anthracis, and Streptococcus aureus, [45]. It is should be noticed that the antibacterial activity of Cltpy ligand is higher than standard antibiotic (gentamicin) against Pseudomonas aeruginosa, Streptococcus pyogenes, and Klebsiella pneumonia. 
Against Escherichia coli, antibacterial activity of complex is higher than Cltpy ligand. The higher activity of complex may be explained on the basis of chelation theory $[42,43]$. Also the better antibacterial activity of complex is probably due to the existence of $\mathrm{I}^{-}$anion in its structure $[44,45]$. The quantitative assays gave MIC values in the range 50$100 \mathrm{mg} \mathrm{ml}^{-1}$ (Table 4) that confirmed the previous results.

\section{Conclusion}

New multidentate ligand, $4^{\prime}$-chloro- $2,2^{\prime}: 6^{\prime}, 2^{\prime \prime}$-terpyridine (Cltpy), has been used for preparation of an inorganic complex. A new $\mathrm{Cd}(\mathrm{II})$ complex $\left[\mathrm{Cd}(\mathrm{Cltpy}) \mathrm{I}_{2}\right]$ has been synthesized and characterized by $\mathrm{CHN}$ elemental analysis, ${ }^{1} \mathrm{H}-\mathrm{NMR},{ }^{13} \mathrm{C}-\mathrm{NMR}$, and IR spectroscopy, and structurally analyzed by $\mathrm{X}$-ray single-crystal diffraction. The singlecrystal X-ray analyses show that the coordination number in this complex is five with three terpyridine (Cltpy) N-donor atoms and two iodine atoms. The antibacterial activities of Cltpy and its $\mathrm{Cd}(\mathrm{II})$ complex are tested against different bacteria. The complex has good activity against all tested bacteria. Against Escherichia coli, antibacterial activity of complex is higher than Cltpy ligand. The higher activity of complex may be explained on the basis of chelation theory.

\section{Additional Data}

CCDC reference number 799987 contains the additional crystallographic data for this paper. These data can be obtained free of charge at http://www.ccdc.cam.ac.uk/conts/retrieving.html.

\section{Acknowledgments}

This work was supported by the Payame Noor University, Khoy in Iran and Facultad de Quimica, Universidade de Vigo, Vigo Pontevedra in Spain.

\section{References}

[1] S. Wang, B. D. Li, R. Y. Wang, B. L. Wu, and H. Y. Zhang, "Synthesis and crystal structure of a novel mixed-valent tricopper complex of 4'-p-tolyl-2,2':6',2'-terpyridine," Synthesis and Reactivity in Inorganic, Metal-Organic and Nano-Metal Chemistry, vol. 39, no. 6, pp. 355-359, 2009.

[2] E. C. Constable, "Expanded ligands-an assembly principle for supramolecular chemistry," Coordination Chemistry Reviews, vol. 252, no. 8-9, pp. 842-855, 2008.

[3] S. K. Padhi, R. Sahu, and V. Manivannan, "Ni(II) complexes of 4'-(2-pyridyl)-2,2':6',2“-terpyridine: structure of mono-and bis-chelates containing anion...П interactions," Polyhedron, vol. 27, no. 9-10, pp. 2221-2225, 2008.

[4] J. p. Sauvage, J. p. Collin, J. C. Chambron et al., "Ruthenium(II) and osmium(II) bis(terpyridine) complexes in covalently-linked multicomponent systems: synthesis, electrochemical behavior, absorption spectra, and photochemical and photophysical properties," Chemical Reviews, vol. 94, no. 4, pp. 993-1019, 1994.

[5] G. J. Meyer, "Molecular approaches to solar energy conversion with coordination compounds anchored to semiconductor surfaces," Inorganic Chemistry, vol. 44, no. 20, pp. 6852-6864, 2005.

[6] S. Bonse, J. M. Richards, S. A. Ross, G. Lowe, and R. L. Krauth-Siegel, "(2,2':6',2“-terpyridine)platinum(II) complexes are irreversible inhibitors of trypanosoma cruzi trypanothione reductase but not of human glutathione reductase," Journal of Medicinal Chemistry, vol. 43, no. 25, pp. 4812-4821, 2000.

[7] G. Chelucci, “Optically active 2,2':6',2“-terpyridine : synthesis of 6-6,6-dimethylnorpynan-2-YL- and 6,6“-BIS-6,6-dimethylnorpynan-2-YL-2,2':6',2“-terpyridine," Synthetic Communications, vol. 23, no. 13, pp. 1897-1903, 1993.

[8] G. Chelucci, M. A. Cabras, and A. Saba, "Enantioselective cyclopropanation of styrene with optically active nitrogen ligands based on the pyridine framework," Journal of Molecular Catalysis, vol. 95, no. 1, pp. L7-L10, 1995.

[9] G. F. Swiegers and T. J. Malefetse, "New self-assembled structural motifs in coordination chemistry," Chemical Reviews, vol. 100, no. 9, pp. 3483-3537, 2000.

[10] J. Chambers, B. Eaves, D. Parker, R. Claxton, p. S. Ray, and S. J. Slattery, "Inductive influence of 4'-terpyridyl substituents on redox and spin state properties of iron(II) and cobalt(II) bis-terpyridyl complexes," Inorganica Chimica Acta, vol. 359, no. 8, pp. 2400-2406, 2006.

[11] W. Huang and H. Qian, "C-H...X hydrogen-bond-mediated supramolecular frameworks: syntheses and crystal structures of hydrochlorate hexafluorophosphorate and hydrochlorate tetrafluoroborate of 4'-chloro-2,2':6',2“-terpyridine,” Journal of Molecular Structure, vol. 832, no. 1-3, pp. 108-116, 2007.

[12] J. M. Lehn, Supramolecular Chemistry, VCH, Weinheim, Germany, 1995.

[13] C. A. Hunter, "Meldola lecture. The role of aromatic interactions in molecular recognition," Chemical Society Reviews, vol. 23, no. 2, pp. 101-109, 1994.

[14] G. R. Desiraju, "Designer crystals: intermolecular interactions, network structures and supramolecular synthons," Chemical Communications, no. 16, pp. 1475-1482, 1997.

[15] M. C. Etter, "Encoding and decoding hydrogen-bond patterns of organic compounds," Accounts of Chemical Research, vol. 23, no. 4, pp. 120-126, 1990.

[16] W. Huang, H. B. Zhu, and S. H. Gou, "Self-assembly directed by dinuclear zinc(II) macrocyclic species," Coordination Chemistry Reviews, vol. 250, no. 3-4, pp. 414-423, 2006.

[17] U. Koch and p. L. A. Popelier, "Characterization of C-H-O hydrogen bonds on the basis of the charge density," Journal of Physical Chemistry, vol. 99, no. 24, pp. 9747-9754, 1995.

[18] J. E. Beves, p. Chwalisz, E. C. Constable et al., "A new polymorph of 4'-tolyl-2,2':6',2"-terpyridine (ttpy) and the single crystal structures of $\left[\mathrm{Fe}(\mathrm{ttpy})_{2}\right]\left[\mathrm{PF}_{6}\right]_{2}$ and $\left[\mathrm{Ru}(\mathrm{ttpy})_{2}\right]\left[\mathrm{PF}_{6}\right]_{2}$," Inorganic Chemistry Communications, vol. 11, no. 9, pp. 10091011, 2008.

[19] W. Huang, W. You, L. Wang, and C. Yao, "Anionic effects on

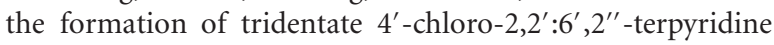
copper(II) complexes having $1: 1$ or $1: 2$ ratio of metal and ligand and their crystal symmetry," Inorganica Chimica Acta, vol. 362, no. 9, p. 2127, 2009.

[20] W. Huang and H. Qian, "Supramolecular frameworks composed of $\mathrm{Ru}(\mathrm{II}), \mathrm{Cu}(\mathrm{II}), \mathrm{Zn}(\mathrm{II}), \mathrm{Ni}(\mathrm{II})$ and $\mathrm{Fe}(\mathrm{II})$ complexes having tridentate 4'-chloro-2,2':6,2“-terpyridine ligand and 1:1 or 1:2 ratios of metal and ligand," Journal of Molecular Structure, vol. 874, no. 1-3, pp. 64-76, 2008.

[21] F. Guo, W. Sun, Y. Liu, and K. Schanze, "Synthesis, photophysics, and optical limiting of platinum(II) 4'-tolylterpyridyl 
arylacetylide complexes," Inorganic Chemistry, vol. 44, no. 11, pp. 4055-4065, 2005.

[22] J. H. Wang, Y. Q. Fang, G. S. Hanan, F. Loiseau, and S. Campagna, "Synthesis and properties of the elusive ruthenium(II) complexes of 4'-cyano-2,2':6',2“-terpyridine," Inorganic Chemistry, vol. 44, no. 1, pp. 5-7, 2005.

[23] C. F. Zhang, H. X. Huang, B. Liu, M. Chen, and D. J. Qiana, "Spectroscopic study on the 4'-(4-pyridyl)-2,2':6',2"terpyridine and its metal complexes," Journal of Luminescence, vol. 128, no. 3, pp. 469-475, 2008.

[24] E. C. Constable, E. L. Dunphy, C. E. Housecroft et al., "Structural development of free or coordinated 4'-(4pyridyl)-2,2':6',2“-terpyridine ligands through N-alkylation: new strategies for metallamacrocycle formation," ChemistryA European Journal, vol. 12, no. 17, pp. 4600-4610, 2006.

[25] G. J. E. Davidson and S. J. Loeb, "Iron(II) complexes utilising terpyridine containing [2] rotaxanes as ligands," Dalton Transactions, no. 22, pp. 4319-4323, 2003.

[26] W. Goodall and J. A. G. Williams, "Iridium(III) bis-terpyridine complexes incorporating pendent $y \mathrm{~V}$-methylpyridinium groups: luminescent sensors for chloride ions," Journal of the Chemical Society, Dalton Transactions, no. 17, pp. 2893-2895, 2000.

[27] H. Feng, X. p. Zhou, T. Wu, D. Li, Y. G. Yin, and S. Weik, "Hydrothermal synthesis of copper complexes of 4'-pyridyl terpyridine: From discrete monomer to zigzag chain polymer," Inorganica Chimica Acta, vol. 362, p. 2127, 2009.

[28] H. Hofmeier and U. S. Schubert, "Recent developments in the supramolecular chemistry of terpyridine-metal complexes," Chemical Society Reviews, vol. 33, p. 373, 2004.

[29] M. A. Halcrow, "The synthesis and coordination chemistry of 2,6-bis(pyrazolyl)pyridines and related ligands-versatile terpyridine analogues," Coordination Chemistry Reviews, vol. 249, no. 24, pp. 2880-2908, 2005.

[30] A. M. W. Cargill Thompson, “The synthesis of 2,':,2“terpyridine ligands—versatile building blocks for supramolecular chemistry," Coordination Chemistry Reviews, vol. 160, pp. 1-52, 1997.

[31] R. A. Fallahpour, "Synthesis of 4'-substituted-2,2':6',2“-terpyridines," Synthesis, no. 2, pp. 155-184, 2003.

[32] G. Chelucci and R. p. Thummel, "Chiral 2,2'-bipyridines, 1,10-phenanthrolines, and 2,2':6',2“-terpyridines: syntheses and applications in asymmetric homogeneous catalysis," Chemical Reviews, vol. 102, no. 9, pp. 3129-3170, 2002.

[33] T. J. Meyer and M. H. V. Huynh, "The remarkable reactivity of high oxidation state ruthenium and osmium polypyridyl complexes," Inorganic Chemistry, vol. 42, no. 25, pp. 8140 8160, 2003.

[34] A. Anthonysamy, S. Balasubramanian, V. Shanmugaiah, and N. Mathivanan, "Synthesis, characterization and electrochemistry of 4'-functionalized 2,2':6',2" -terpyridine ruthenium(II) complexes and their biological activity," Dalton Transactions, no. 16, pp. 2136-2143, 2008.

[35] M. J. Maclachlan, M. Ginzburg, N. Coombs et al., "Shaped ceramics with tunable magnetic properties from metalcontaining polymers," Science, vol. 287, no. 5457, pp. 1460$1463,2000$.

[36] M. J. Clarke, F. Zhu, and D. R. Frasca, "Non-platinum chemotherapeutic metallopharmaceuticals," Chemical Reviews, vol. 99, no. 9, pp. 2511-2533, 1999.

[37] S. D. Cummings, "Platinum complexes of terpyridine: interaction and reactivity with biomolecules," Coordination Chemistry Reviews, vol. 253, no. 9-10, pp. 1495-1516, 2009.
[38] L. R. Kelland, "Meeting report on 8th international symposium on platinum and other metal coordination compounds in cancer chemotherapy," Journal of Inorganic Biochemistry, vol. 77, no. 1-2, pp. 121-124, 1999.

[39] G. Lowe, A. S. Droz, T. Vilaivan et al., "Cytotoxicity of 2,2':6',2“-terpyridineplatinum(II) complexes against human ovarian carcinoma," Journal of Medicinal Chemistry, vol. 42, no. 16, pp. 3167-3174, 1999.

[40] E. Ispir and M. Kurtoglu, "The $\mathrm{d}^{10}$ metal chelates derived from schiff base ligands having silane: synthesis, characterization, and antimicrobial studies of cadmium(II) and zinc(II) complexes," Synthesis and Reactivity in Inorganic, Metal-Organic and Nano-Metal Chemistry, vol. 36, no. 8, pp. 627-631, 2006.

[41] B. Barszcz, A. A. Wawrzycka, K. Stadnicka, and S. A. Hodorowicz, "The synthesis and structural characterization of novel zinc and cadmium complexes of chelating alcohol," Inorganic Chemistry Communications, vol. 8, no. 10, pp. 951-954, 2005.

[42] L. A. Saghatforoush, F. Chalabian, A. Aminkhani, G. Karimnezhad, and S. Ershad, "Synthesis, spectroscopic characterization and antibacterial activity of new cobalt(II) complexes of unsymmetrical tetradentate (OSN) Schiff base ligands," European Journal of Medicinal Chemistry, vol. 44, no. 11, pp. 4490-4495, 2009.

[43] K. B. Chew, M. T. H. Tarafder, K. A. Crouse, A. M. Ali, B. M. Yamin, and H. K. Fun, "Synthesis, characterization and bioactivity of metal complexes of bidentate N-S isomeric Schiff bases derived from $S$-methyldithiocarbazate(SMDTC) and the X-ray structure of the bis[S(2-furyl-methyl- $\beta$ - $N$-(2-urylmethylketone)dithiocarbazato]cadmium(II) complex," Polyhedron, vol. 23, no. 8, pp. 1385-1392, 2004.

[44] S. D. Cummings, "Platinum complexes of terpyridine: interaction and reactivity with biomolecules," Coordination Chemistry Reviews, vol. 253, no. 9-10, pp. 1495-1516, 2009.

[45] A. Jain, B. S. J. Winkel, and K. J. Brewer, "In vivo inhibition of E. coli growth by a $\mathrm{Ru}(\mathrm{II}) / \mathrm{Pt}(\mathrm{II})$ supramolecule $\left[(\mathrm{tpy}) \mathrm{RuCl}(\mathrm{dpp}) \mathrm{PtCl}_{2}\right]\left(\mathrm{PF}_{6}\right)$," Journal of Inorganic Biochemistry, vol. 101, no. 10, pp. 1525-1528, 2007.

[46] G. M. Sheldrick, SHELXL97. Program for the Refinement of Crystal Structures, University of Gottingen, Gottingen, Germany, 1997.

[47] L. J. Farrugia, "ORTEP-3 for windows-a version of ORTEPIII with a graphical user interface (GUI)," Journal of Applied Crystallography, vol. 30, no. 5, p. 565, 1997.

[48] Mercury 1.4.1, Copyright Cambridge Crystallographic Data Centre, 12 Union Road, Cambridge, CB2 1EZ, UK, 20012005.

[49] E. C. Constable, "The coordination cemistry of $2,2^{\prime}: 6^{\prime}, 2^{\prime \prime}-$ terpyridine and higher oligopyridines," Academic Press Inc., vol. 30, p. 69, 1986.

[50] A. W. Addison, T. N. Rao, J. Reedijk, J. Van Rijn, and G. C. Verschoor, "Synthesis, structure, and spectroscopic properties of copper(II) compounds containing nitrogen-sulphur donor ligands; the crystal and molecular structure of aqua[1,7-bis $(\mathrm{N}-$ methylbenzimidazol-2'-yl)-2,6-dithiaheptane]copper(II) perchlorate," Journal of the Chemical Society, Dalton Transactions, no. 7, pp. 1349-1356, 1984.

[51] D. Reinen and C. Friebel, "Cu in 5-coordination: a case of a second-order Jahn-Teller effect. 2. $\mathrm{CuCl}$ and other $\mathrm{CuL}$ complexes: trigonal bipyramid or square pyramid?" Inorganic Chemistry, vol. 23, no. 7, pp. 791-798, 1984.

[52] p. Manikandan, K. R. J. Thomas, and p. T. Manoharan, "Structural and spectral diversities in copper(n) complexes of 2,6-bis(3,5-dimethylpyrazol-1-ylmethyl)pyridine," Journal 
of the Chemical Society, Dalton Transactions, no. 16, pp. 27792785, 2000.

[53] E. S. Lang, R. Stieler, and G. N. M. de Oliveira, "Synthesis, structural characterization and growth features of some $(\mathrm{Ph}) \mathrm{Se}-\mathrm{Cd}$ cluster compounds $(\mathrm{Ph}=$ phenyl)," Polyhedron, vol. 29, no. 7, pp. 1760-1763, 2010.

[54] W. You, W. Huang, Y. Fan, and C. Yao, "Studies on two cadmium(II) and two zinc(II) complexes of 4'-chloro-2,2': 6'2"-terpyridine with 1:1 or 1:2 ratio of metal and ligand," Journal of Coordination Chemistry, vol. 62, no. 13, pp. 21252137, 2009.

[55] M. A. Harvey, S. Baggio, M. T. Garland, and R. Baggio, "Xray study of two new cadmium acetato complexes," Journal of Coordination Chemistry, vol. 58, no. 3, pp. 243-253, 2005. 


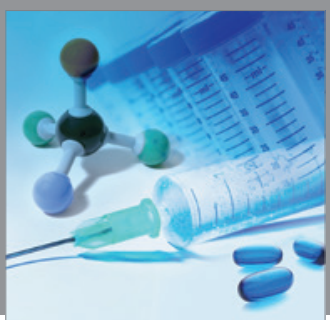

International Journal of

Medicinal Chemistry

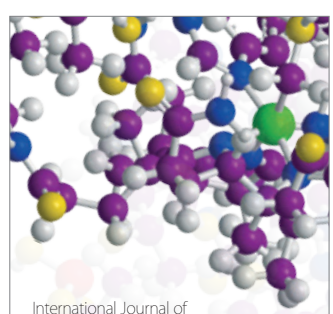

Carbohydrate Chemistry

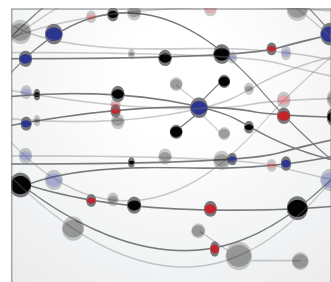

The Scientific World Journal
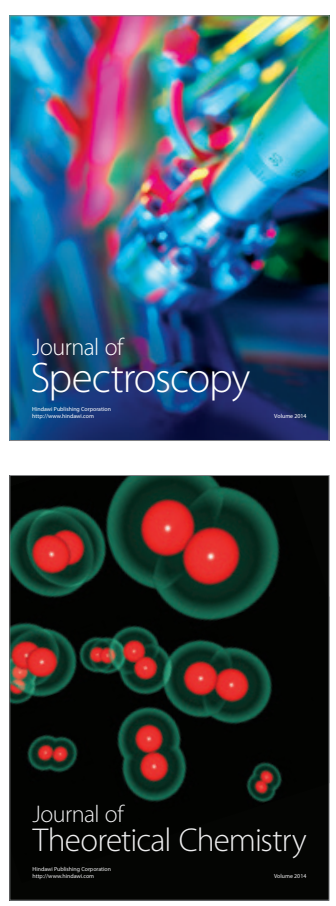
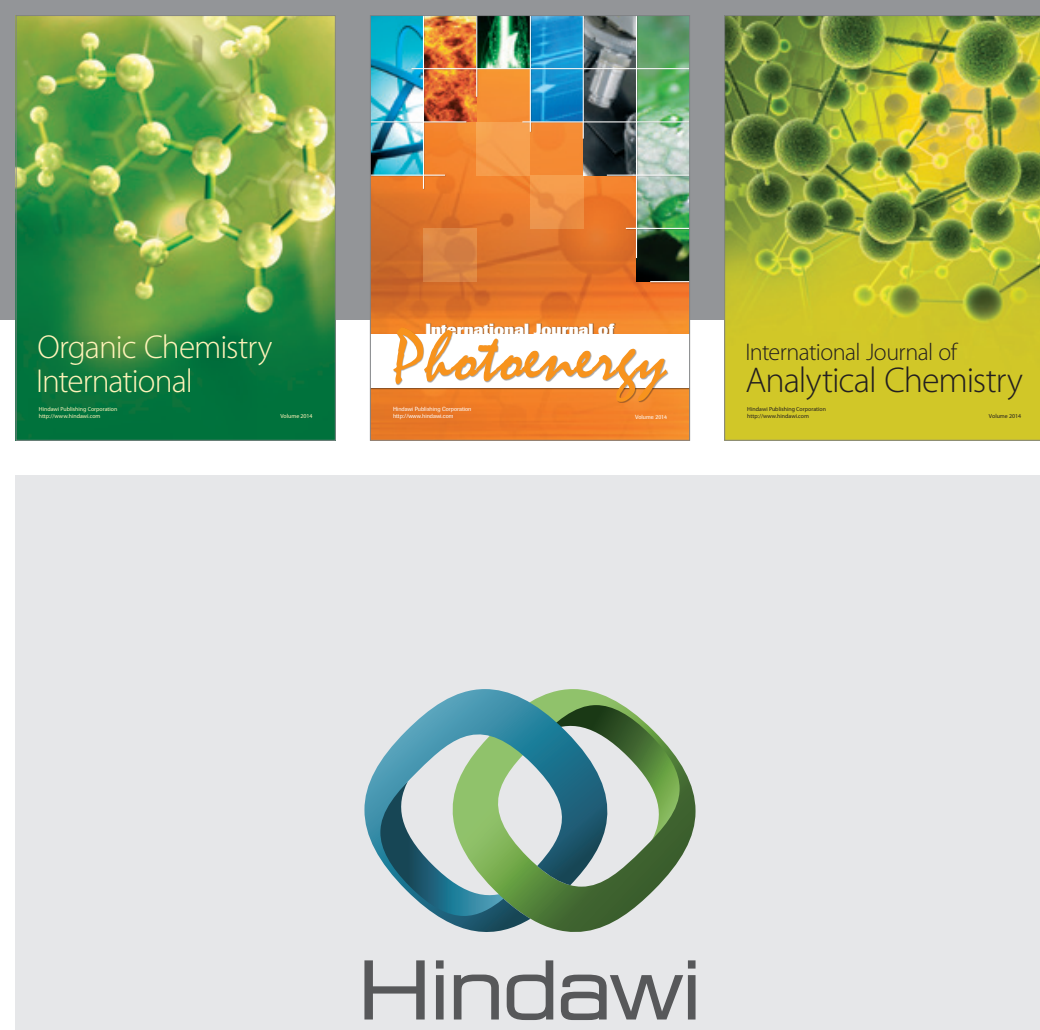

Submit your manuscripts at

http://www.hindawi.com
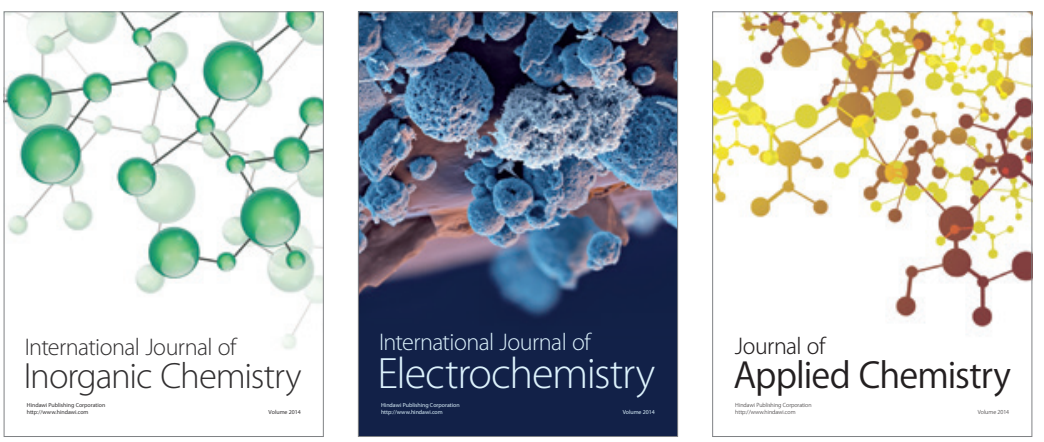

Journal of

Applied Chemistry
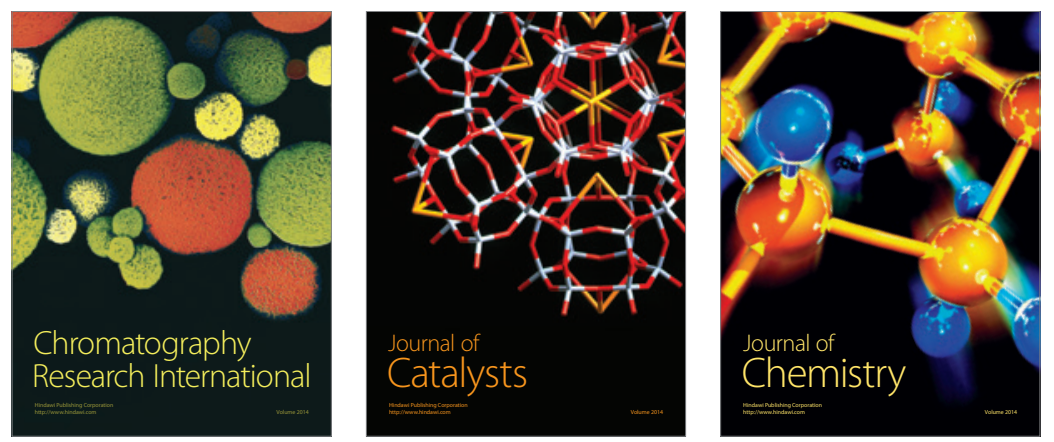
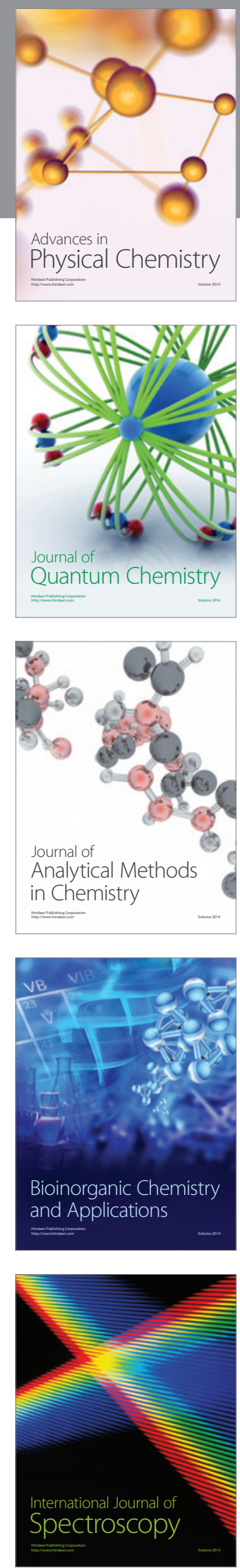